University of Nebraska - Lincoln

DigitalCommons@University of Nebraska - Lincoln

USDA Wildlife Services - Staff Publications

U.S. Department of Agriculture: Animal and Plant Health Inspection Service

2012

\title{
The role of a generalized ultraviolet cue for blackbird food selection
}

\author{
Scott J. Werner \\ USDA-APHIS-Wildlife Services, scott.j.werner@aphis.usda.gov \\ Shelagh K. Tupper \\ USDA/APHIS/WS/National Wildlife Research Center \\ James C. Carlson \\ USDA/APHIS/WS/National Wildlife Research Center, james.c.carlson@aphis.usda.gov \\ Susan E. Pettit \\ USDA/APHIS/WS/National Wildlife Research Center \\ Jeremy W. Ellis \\ USDA-APHIS-Wildlife Services
}

See next page for additional authors

Follow this and additional works at: https://digitalcommons.unl.edu/icwdm_usdanwrc

Part of the Environmental Sciences Commons

Werner, Scott J.; Tupper, Shelagh K.; Carlson, James C.; Pettit, Susan E.; Ellis, Jeremy W.; and Linz, George
M., "The role of a generalized ultraviolet cue for blackbird food selection" (2012). USDA Wildlife Services -
Staff Publications. 1071. https://digitalcommons.unl.edu/icwdm_usdanwrc/1071

This Article is brought to you for free and open access by the U.S. Department of Agriculture: Animal and Plant Health Inspection Service at DigitalCommons@University of Nebraska - Lincoln. It has been accepted for inclusion in USDA Wildlife Services - Staff Publications by an authorized administrator of DigitalCommons@University of Nebraska - Lincoln. 


\section{Authors}

Scott J. Werner, Shelagh K. Tupper, James C. Carlson, Susan E. Pettit, Jeremy W. Ellis, and George M. Linz 


\title{
The role of a generalized ultraviolet cue for blackbird food selection
}

\author{
Scott J. Werner ${ }^{\text {a,* }}$, Shelagh K. Tupper a , James C. Carlson ${ }^{\text {a }}$, Susan E. Pettit ${ }^{\mathrm{a}}$, \\ Jeremy W. Ellis ${ }^{\mathrm{a}}$, George M. Linz ${ }^{\mathrm{b}}$ \\ a USDA/APHIS/WS/National Wildlife Research Center, 4101 LaPorte Avenue, Fort Collins, CO 80521-2154, United States \\ ${ }^{\mathrm{b}}$ USDA/APHIS/WS/National Wildlife Research Center, North Dakota Field Station, 2110 Miriam Circle, Suite B, Bismarck, ND 58501-2502, United States
}

\section{A R T I C L E I N F O}

\section{Article history:}

Received 21 December 2011

Received in revised form 5 April 2012

Accepted 6 April 2012

Available online 14 April 2012

\section{Keywords:}

Agelaius phoeniceus

Conditioned avoidance

Feeding behavior

Postingestive consequence

Red-winged blackbird

Visual cue

\begin{abstract}
A B S T R A C T
Birds utilize ultraviolet (UV) wavelengths for plumage signaling and sexual selection. Ultraviolet cues may also be used for the process of avian food selection. The aim of our study was to investigate whether a UV cue and a postingestive repellent can be used to condition food avoidance in red-winged blackbirds (Agelaius phoeniceus). We found that birds conditioned with an UV-absorbent, postingestive repellent subsequently avoided UV-absorbent food. Thus, the UV-absorbent cue (coupled with $0-20 \%$ of the conditioned repellent concentration) was used to maintain avoidance for up to 18 days post-conditioning. Similarly, birds conditioned with the UV-absorbent, postingestive repellent subsequently avoided UV-reflective food. Thus, conditioned avoidance of an UV-absorbent cue can be generalized to an unconditioned, UV-reflective cue for nutrient selection and toxin avoidance. These findings support the hypothesized function of UV vision for avian food selection, the implications of which remain to be explored for the sensory and behavioral ecology within agronomic and natural environments.
\end{abstract}

Published by Elsevier Inc.
Relative to humans, avian color vision is characterized by a wider spectral range, more cone types in the retina, and colored oil droplets that filter the light entering the cones [1,2]. Ultraviolet (UV) vision has been identified in wild birds for nearly 40 years [3,4]. For birds, UV vision is hypothesized to have functional significance for several ecological processes, including orientation, plumage signaling, and foraging behavior [1,5]. Like bees, some birds are thought to use UV wavelengths for orientation [see reviews of Refs. 1,5]. Unlike bees, polarization detection among birds is not linked exclusively to UV receptors; the bee system of navigation is therefore not a logical necessity for birds [5]. With regard to plumage signaling and sexual selection, Pekin robins (Leiothrix lutea) prefer a partner viewed through UV-transparent plexiglass over a partner viewed through UV-opaque material [6]. Similarly, European starlings [Sturnus vulgaris; 7] and zebra finches [Taeniopygia guttata; 7,8] prefer to associate with conspecifics viewed through a UV-transmitting filter over those viewed through a UV-blocking filter.

With regard to feeding behavior, birds are thought to use UV signals for detecting foods that either absorb or reflect UV wavelengths [5]. For example, previous studies investigated the use of UV reflectance for avian detection of mammalian prey [9], insect prey [10], and mature fruit [11]. Beyond the detection and recognition of food items [12,13], UV cues may also provide birds with information regarding the quality of foods [e.g., quality or ripeness of fruit; 1,14].

\footnotetext{
* Corresponding author. Tel.: +1970 266 6136; fax: +1970266 6138 E-mail address: Scott.J.Werner@aphis.usda.gov (S.J. Werner).
}

Indeed, age and/or learning may affect frugivore preference for UV reflectance associated with ripe fruit $[15,16]$. Thus, UV cues may be specifically related to postingestive consequences of the subsequent reinforcer [17] and the process of food selection may be a function of its consequences [18] for wild birds. Further investigation is needed to understand how birds use UV cues for feeding behavior [1].

We tested two hypotheses. Red-winged blackbirds (Agelaius phoeniceus) are regarded as the primary cause of agricultural depredation to newly-planted rice in spring, and ripening sunflower and rice in fall; thus, experimental investigations regarding the process of blackbird food selection are warranted. Our first hypothesis was that a UV cue and a postingestive repellent can be used to condition avoidance in red-winged blackbirds [19, B. A. Kimball, M. Cheney \& F. D. Provenza, unpublished data]. Previous studies demonstrated conditioned color avoidance $[20,21]$ and UV vision $[22,23]$ in redwinged blackbirds. Moreover, red-winged blackbirds associate preand postingestive consequences with food color, and reliably integrate visual and gustatory experience with postingestive consequences to procure nutrients and avoid toxins [24]. We therefore conducted Experiment 1 to investigate the role of UV cues for the process of blackbird food selection.

Our second hypothesis was that UV cues could be generalized for nutrient selection and toxin avoidance. In contrast to green-treated food, red-winged blackbirds avoid unconditioned shades of red subsequent to postingestive conditioning with red-treated food [25]. Thus, we conducted Experiment 2 to determine if avoidance conditioned with a UV-absorbent, postingestive repellent could be generalized to a UV-reflective cue. 


\section{General methods}

\subsection{Bird subjects and testing facilities}

Red-winged blackbirds were live-captured in northern Colorado under Scientific Collection Permits authorized by the U. S. Fish and Wildlife Service (MB019065) and the Colorado Division of Wildlife (11TRb2006). We used a baited cannon net to capture adult blackbirds, and they were transported in isolated bird carriers $(61 \mathrm{~cm} \times 43 \mathrm{~cm} \times 11 \mathrm{~cm} ; 20$ birds per carrier) to the National Wildlife Research Center's (NWRC) outdoor animal research facility within $1 \mathrm{~h}$ post-capture. All blackbirds were quarantined at NWRC for at least two weeks prior to our experiments within group cages ( $6 \mathrm{~m} \times 3 \mathrm{~m} \times 3 \mathrm{~m} ; 40-50$ birds per cage).

Daily food consumption was measured independently for the east and west food bowls offered throughout Experiments 1 and 2. Unconsumed sunflower (remaining in food bowls) and spillage were collected at $0800 \mathrm{~h}$, daily, and weighed $( \pm 0.1 \mathrm{~g})$. Weight change (e.g., desiccation) was measured daily by weighing sunflower offered within a vacant cage throughout the experiments.

Ambient temperature was $-13{ }^{\circ} \mathrm{C}$ on conditioning day 2 of our first experiment; as an alternative to no-choice of repellent-treated food, we therefore provided one bowl of untreated food and one bowl of repellent-treated food on conditioning day 2 of our feeding experiments (Tables 1 and 2). We realized two blackbird mortalities during the test of our first experiment, and one mortality during each of the conditioning and testing phases of our second experiment. Experimental protocols were approved by the NWRC Institutional Animal Care and Use Committee (QA-1729; S. J. Werner-Study Director).

\subsection{Statistical analyses}

The dependent measure for our feeding experiments was average consumption of treated and untreated sunflower throughout each test. After successfully conducting Levene's test for equal variances ( $\alpha=0.05$ ), we evaluated the group-by-treatment interaction of our first experiment using a general linear model (SAS v9.2). We used Welch's ANOVA to analyze the heteroscedastic consumption data associated with our second experiment [26]. The random effect of our models was bird cages, and the between-subjects effects were seed treatments (treated and untreated) and test groups. We used Tukey's tests to separate the means of significant interactions $(\alpha=0.05)$, and descriptive statistics $(\bar{x} \pm \mathrm{SE})$ and preference ratios to summarize and illustrate test consumption, respectively.

\section{Experiment one}

\subsection{Method}

We used avoidance conditioning to investigate the role of an UV cue for blackbird food selection. For our first experiment, we used

\section{Table 1}

Treatment schedule for conditioning with an anthraquinone-based repellent ( $A Q)$ and testing conditioned avoidance of an ultraviolet-absorbent cue (titanium dioxide; $\mathrm{TiO}_{2}$ ).

\begin{tabular}{|c|c|c|c|}
\hline \multirow[t]{2}{*}{ Period } & \multirow[t]{2}{*}{ Group ( $n$ cages) } & \multicolumn{2}{|l|}{ Seed treatment } \\
\hline & & Bowl 1 & Bowl 2 \\
\hline \multirow[t]{3}{*}{ Conditioning } & 1 (24, conditioned) & Day $1: 0.25 \%$ AQ & Day 1: $0.25 \% \mathrm{AQ}$ \\
\hline & & Day 2: $0.25 \% \mathrm{AQ}$ & Day 2: $0 \% \mathrm{AQ}$ \\
\hline & 2 (8, unconditioned) & Days 1 and 2: $0 \% \mathrm{AQ}$ & $\begin{array}{l}\text { Days } 1 \text { and } 2 \text { : } \\
0 \% \text { AQ }\end{array}$ \\
\hline \multirow[t]{4}{*}{ Test } & $1 \mathrm{~A}(8)$ & $0 \% \mathrm{AQ}+0.2 \% \mathrm{TiO}_{2}$ & $0 \% \mathrm{AQ}+0 \% \mathrm{TiO}_{2}$ \\
\hline & 1B (8) & $0.025 \% \mathrm{AQ}+0.2 \% \mathrm{TiO}_{2}$ & $0 \% \mathrm{AQ}+0 \% \mathrm{TiO}_{2}$ \\
\hline & $1 C(8)$ & $0.05 \% \mathrm{AQ}+0.2 \% \mathrm{TiO}_{2}$ & $0 \% \mathrm{AQ}+0 \% \mathrm{TiO}_{2}$ \\
\hline & $2 \mathrm{~A}(8)$ & $0 \% \mathrm{AQ}+0.2 \% \mathrm{TiO}_{2}$ & $0 \% \mathrm{AQ}+0 \% \mathrm{TiO}_{2}$ \\
\hline
\end{tabular}

Table 2

Treatment schedule for conditioning with an anthraquinone-based repellent (AQ) and testing conditioned avoidance of an ultraviolet-reflective cue (magnesium carbonate; $\left.\mathrm{MgCO}_{3}\right)$.

\begin{tabular}{llll}
\hline \multirow{2}{*}{ Period } & Group ( $n$ cages $)$ & Seed treatment \\
\cline { 3 - 4 } & & Bowl 1 & Bowl 2 \\
\hline \multirow{2}{*}{ Conditioning } & $1(10$, conditioned) & Day 1: $0.25 \% \mathrm{AQ}$ & Day $1: 0.25 \% \mathrm{AQ}$ \\
& & Day 2: $0.25 \% \mathrm{AQ}$ & Day 2: $0 \% \mathrm{AQ}$ \\
\multirow{2}{*}{ Test } & $2(10$, unconditioned) & Days 1 and $2: 0 \% \mathrm{AQ}$ & Days 1 and $2: 0 \% \mathrm{AQ}$ \\
& $1(10)$ & $0 \% \mathrm{AQ}+0.2 \% \mathrm{MgCO}_{3}$ & $0 \% \mathrm{AQ}+0 \% \mathrm{MgCO}_{3}$ \\
& $2(10)$ & $0 \% \mathrm{AQ}+0.2 \% \mathrm{MgCO}_{3}$ & $0 \% \mathrm{AQ}+0 \% \mathrm{MgCO}_{3}$ \\
\hline
\end{tabular}

an anthraquinone-based repellent to condition food avoidance (Avipel®; Arkion Life Sciences, New Castle, DE, U.S.A.) and a titanium dioxide cue for subsequent preference testing (Evonik Goldschmidt Corporation, Hopewell, VA, U.S.A.). Anthraquinone is a cathartic, emodin purgative [27]. We used a Genesys ${ }^{\mathrm{TM}} 2,336002$ spectrophotometer (Thermo Spectronic US, Rochester, NY, U.S.A.) to determine that both the Avipel repellent and the titanium dioxide cue absorb near UV wavelengths (Fig. 1).

Male red-winged blackbirds ( $N=160$, experimentally naïve) acclimated within 32 group cages $(4.9 \mathrm{~m} \times 2.4 \mathrm{~m} \times 2.4 \mathrm{~m}$; five birds per cage) in an outdoor aviary for five days. The outdoor aviary consists of a wire mesh-sided building designed to maintain blackbirds and starlings in an outdoor environment. We offered two food bowls (east and west side of cage) of unadulterated sunflower in each cage throughout the acclimation period. Two food bowls (each containing $75 \mathrm{~g}$ of unadulterated sunflower) were subsequently offered at $0800 \mathrm{~h}$, daily for two pre-test days. We ranked cages based upon food consumption and assigned each cage to conditioning groups upon completion of the pre-test (Table 1), such that each group was similarly populated with cages that exhibited high-low food consumption [28-30]. We randomly assigned conditioning treatments between groups.

The conditioned group (Table 1 ) received $75 \mathrm{~g}$ of sunflower achenes treated with the Avipel UV-absorbent, postingestive repellent ( $0.25 \%$ anthraquinone) in each of two food bowls on conditioning day 1 , and one bowl each of unadulterated sunflower and Avipeltreated sunflower $(0.25 \%$ anthraquinone) on conditioning day 2 (see Bird Subjects and Testing Facilities). We formulated seed treatments by applying aqueous suspensions to oilseed sunflower $[60 \mathrm{ml} / \mathrm{kg}$; 28-30]. The unconditioned group (Table 1 ) received $75 \mathrm{~g}$ of unadulterated sunflower achenes in both food bowls for two days. We

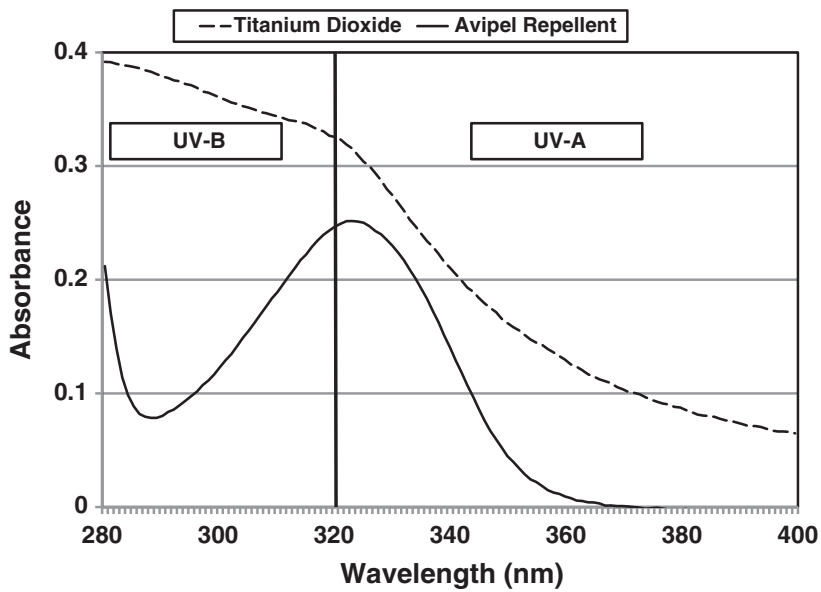

Fig. 1. Mean absorbance spectra for the titanium dioxide cue (Evonik Goldschmidt Corporation, Hopewell, VA, U.S.A.) and the anthraquinone-based repellent (Avipel®; Arkion Life Sciences, New Castle, DE, U.S.A.) used to test conditioned food avoidance among red-winged blackbirds. 


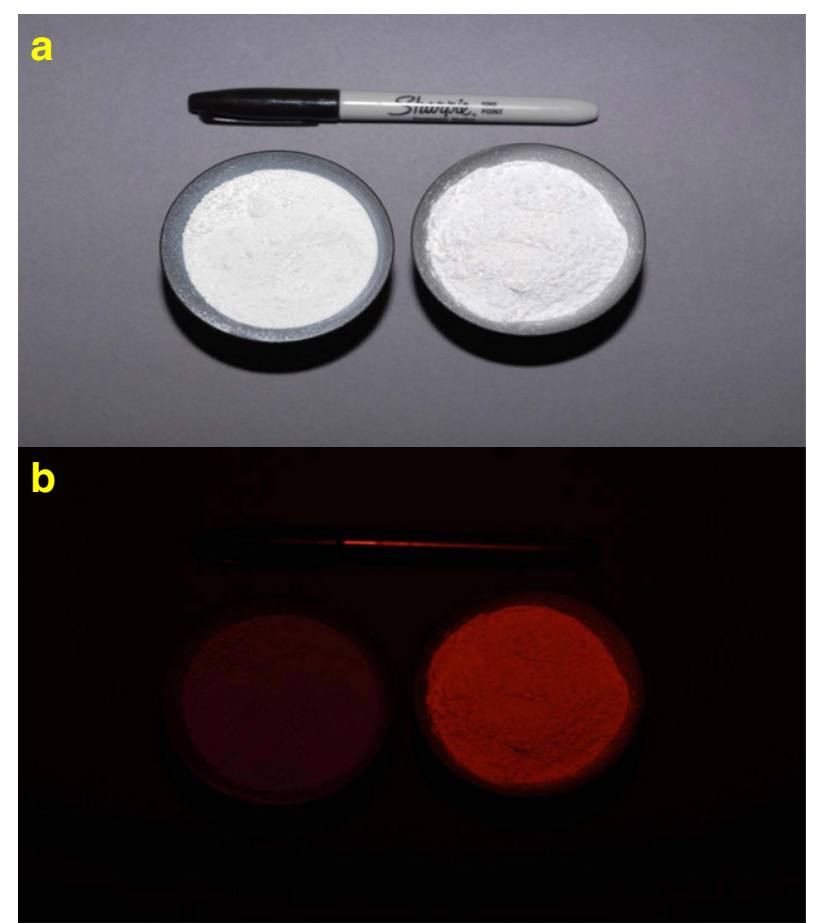

Fig. 2. Human-visible (a) and UV images (b) of the UV-absorbent, titanium dioxide cue (left; Evonik Goldschmidt Corporation, Hopewell, VA, U.S.A.) and the UV-reflective, magnesium carbonate cue (right; Sigma-Aldrich, Inc., Bellefonte, PA, U.S.A.) used to test conditioned food avoidance among red-winged blackbirds. Digital images were created using a modified Nikon D200 (Nikon, Inc., Melville, NY, U.S.A.), CoastalOpt ${ }^{\circledR}$ $60 \mathrm{~mm}$ UV-VIS-IR APO macro (Jenoptik Optical Systems, Inc., Jupiter, FL, U.S.A.), Baader 300-400 nm bandpass filter (Alpine Astronomical, Eagle, ID, U.S.A.), and a modified Vivitar 285 HV flash (Vivitar, Edison, NJ, U.S.A.).

ranked conditioned cages based upon food consumption and assigned each cage to one of three test groups such that each group was similarly populated with cages that exhibited high-low food consumption. We randomly assigned test treatments among groups (Table 1). We offered two food bowls of the maintenance diet (two parts millet: one cracked corn: one milo: one safflower) during the three days subsequent to conditioning.

For the next 14 days, all birds were offered a choice between unadulterated sunflower and sunflower treated with an UVabsorbent cue (75 g each). Treated food for Groups 1A (conditioned) and $2 \mathrm{~A}$ (unconditioned) included $0 \%$ anthraquinone and $0.2 \%$ titanium dioxide (Table 1 ). For comparison, treated food for groups $1 \mathrm{~B}$ and $1 \mathrm{C}$ included $0.2 \%$ titanium dioxide and $0.025 \%$ anthraquinone or $0.05 \%$ anthraquinone, respectively. We randomized the east-west placement of food bowls on test day 1, and thereafter alternated bowls daily, throughout the test. We independently measured daily sunflower consumption in both food bowls in each cage throughout the test.

\subsection{Results and discussion}

The four test groups consumed different amounts of treated and untreated food during the 14-day preference test $\left(F_{7,56}=166.29\right.$, $P<0.0001$; Fig. 3). Birds conditioned with the Avipel UV-absorbent, postingestive repellent avoided sunflower treated only with the UVabsorbent cue throughout the test (titanium dioxide and $0 \%$ anthraquinone; Fig. 3). This group (1A) consumed an average of $5.0 \pm 1.0 \mathrm{~g}$ of sunflower treated with titanium dioxide plus $0 \%$ anthraquinone, and $31.3 \pm 1.2 \mathrm{~g}$ of untreated sunflower per day (Tukey $P<0.0001$ ).

Similarly, blackbirds conditioned with the anthraquinone-based repellent also avoided sunflower treated with titanium dioxide and $0.025 \%$ anthraquinone (Group 1B) or 0.05\% anthraquinone (Group

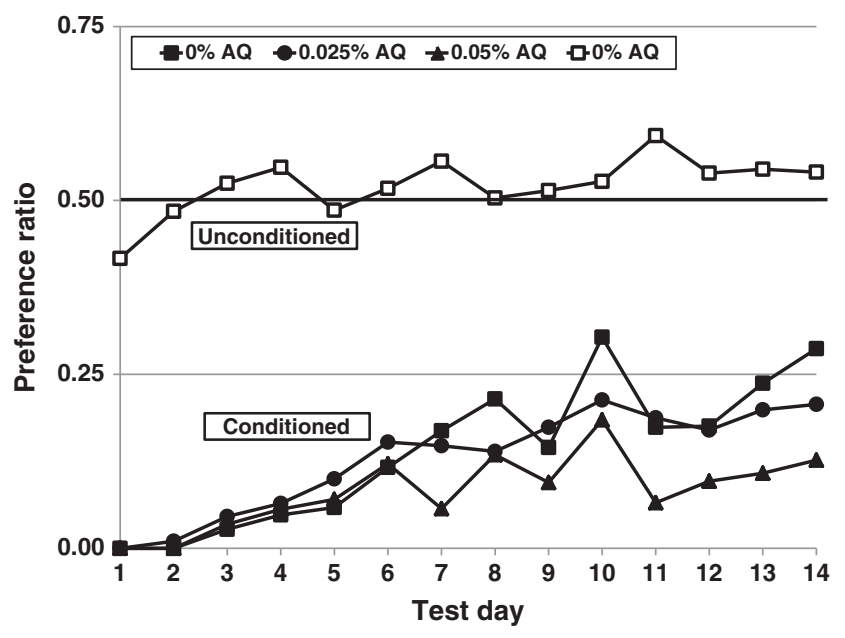

Fig. 3. Preference ratios for four test groups ( $n=$ eight cages per group, five red-winged blackbirds per cage) offered untreated food and food treated with an UV-absorbent cue during a 14-day preference test. Preference ratios $>0.5$ indicate food preference; ratios $<0.5$ indicate food avoidance. Three conditioned groups (filled shapes) were exposed to an UV-absorbent, postingestive repellent (anthraquinone; AQ) during a two-day conditioning period (four days prior to the test). The unconditioned group (unfilled squares) was exposed to unadulterated sunflower during the two-day conditioning period.

1C) throughout the test (Fig. 3). Group 1B consumed an average of $4.8 \pm 0.7 \mathrm{~g}$ of sunflower treated with titanium dioxide plus $0.025 \%$ anthraquinone, and $32.5 \pm 1.0 \mathrm{~g}$ of untreated sunflower per day (Tukey $P<0.0001$ ). Group 1C consumed an average of $3.0 \pm 0.5 \mathrm{~g}$ of sunflower treated with titanium dioxide plus $0.05 \%$ anthraquinone, and $33.0 \pm$ $0.7 \mathrm{~g}$ of untreated sunflower per day (Tukey $P<0.0001$ ).

In contrast, unconditioned birds consumed similar amounts of unadulterated sunflower and sunflower treated with titanium dioxide throughout the test (Fig. 3). The unconditioned group (2A) consumed an average of $19.0 \pm 0.7 \mathrm{~g}$ of sunflower treated with titanium dioxide plus $0 \%$ anthraquinone, and $17.3 \pm 0.3 \mathrm{~g}$ of untreated sunflower per day (Tukey $P=0.933$ ). Thus, the UV-absorbent cue was used to maintain conditioned avoidance for up to 18 days after conditioning with an UV-absorbent, postingestive repellent. Moreover, UV-absorbent food, with and without persistent repellent consequences (i.e., paired with $0-20 \%$ of the conditioned repellent concentration), was equally aversive to blackbirds after two days of conditioning (Tukey $P>0.85$ ).

\section{Experiment two}

\subsection{Method}

In order to test whether blackbirds might also generalize among UV feeding cues, we repeated the UV-absorbent conditioning of our first experiment and tested subsequent preference for sunflower treated with an UV-reflective cue [31; 0.2\% magnesium carbonate, Sigma-Aldrich, Inc., Bellefonte, PA, U.S.A.]. We used UV digital photography to compare the UV-absorbent and UV-reflective cues used during the test of our first and second experiments, respectively (Fig. 2).

Male red-winged blackbirds ( $N=60$, experimentally naïve) acclimated within 20 group cages $(4.9 \mathrm{~m} \times 2.4 \mathrm{~m} \times 2.4 \mathrm{~m}$; three birds per cage) in the outdoor aviary for five days. We offered two food bowls (east and west side of cage) of unadulterated sunflower in each cage throughout the acclimation period. Two food bowls (each containing $75 \mathrm{~g}$ of unadulterated sunflower) were subsequently offered at $0800 \mathrm{~h}$, daily for two pre-test days. We ranked cages based upon food consumption and assigned each cage to conditioning groups upon completion of the pre-test (Table 2), such that each group was similarly populated with cages that exhibited high-low food consumption. We randomly assigned conditioning treatments between groups. 


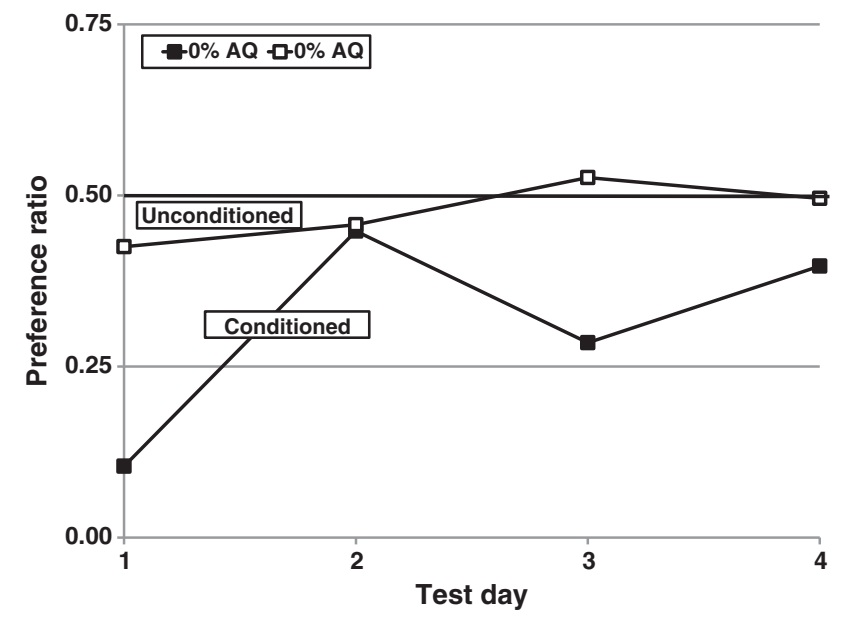

Fig. 4. Preference ratios for two test groups ( $n=10$ cages per group, three red-winged blackbirds per cage) offered untreated food and food treated with an UV-reflective cue during a four-day preference test. Preference ratios $>0.5$ indicate food preference; ratios $<0.5$ indicate food avoidance. The conditioned group (filled squares) was exposed to an UV-absorbent, postingestive repellent (anthraquinone; AQ) during a two-day conditioning period (four days prior to the test). The unconditioned group (unfilled squares) was exposed to unadulterated sunflower during the two-day conditioning period.

The conditioned group (Table 2) received $75 \mathrm{~g}$ of sunflower achenes treated with the Avipel UV-absorbent, postingestive repellent $(0.25 \%$ anthraquinone) in each of two food bowls on conditioning day 1 , and one bowl each of unadulterated sunflower and Avipeltreated sunflower ( $0.25 \%$ anthraquinone) on conditioning day 2 . The unconditioned group (Table 2 ) received $75 \mathrm{~g}$ of unadulterated sunflower achenes in both food bowls for two days. We offered two food bowls of the maintenance diet during the three days subsequent to conditioning.

For the next four days, all birds were offered a choice between unadulterated sunflower and sunflower treated with an UV-reflective cue ( $75 \mathrm{~g}$ each). Treated food for Groups 1 (conditioned) and 2 (unconditioned) included $0 \%$ anthraquinone and $0.2 \%$ magnesium carbonate (Table 2). We randomized the east-west placement of food bowls on test day 1 , and thereafter alternated bowls daily, throughout the test. We independently measured daily sunflower consumption in both food bowls in each cage throughout the test.

\subsection{Results and discussion}

The two test groups consumed different amounts of treated and untreated food during the four-day preference test $\left(F_{3,20}=9.45\right.$, $P<0.001$; Fig. 4). Interestingly, blackbirds conditioned with the UV-absorbent, postingestive repellent avoided sunflower treated only with the UV-reflective cue throughout the test (magnesium carbonate and $0 \%$ anthraquinone; Fig. 4). The conditioned group consumed an average of $7.1 \pm 0.8 \mathrm{~g}$ of sunflower treated with magnesium carbonate plus $0 \%$ anthraquinone, and $15.4 \pm 0.9 \mathrm{~g}$ of untreated sunflower per day (Tukey $P<0.0001$ ). The unconditioned group consumed an average of $9.7 \pm 0.4 \mathrm{~g}$ of sunflower treated with magnesium carbonate plus $0 \%$ anthraquinone, and $10.7 \pm 0.4 \mathrm{~g}$ of untreated sunflower per day (Tukey $P=0.872$ ). Thus, conditioned avoidance of an UV-absorbent cue was generalized to an unconditioned, UV-reflective cue.

\section{General discussion}

Red-winged blackbirds avoided UV-absorbent food subsequent to conditioning with a UV-absorbent, postingestive repellent. Thus, the UV-absorbent cue (coupled with $0-20 \%$ of the conditioned repellent concentration) was used to maintain avoidance for up to 18 days post-conditioning. Ultraviolet cues were therefore specifically related to postingestive consequences of the subsequent reinforcer [17] and the process of food selection can be regarded as a function of its consequences [18] for blackbirds.

These findings support the hypothesized function of UV vision for avian food selection. Ultraviolet cues alone, however, are unlikely to elicit food avoidance among wild birds [32]. Blackbirds use affective processes [i.e., flavor-feedback relationships; 33,34] to shift preference for both novel and familiar flavors, and cognitive associations (colors) to avoid food, subsequent to toxin exposure [21]. These "colors" include UV-absorbent and UV-reflective cues for blackbird feeding behavior.

Blackbirds also avoided UV-reflective food subsequent to conditioning with the UV-absorbent, postingestive repellent. Perhaps blackbirds in Experiments 1 and 2 simply avoided adulterated food subsequent to conditioning. Alternatively, we conclude that conditioned avoidance of the UV-absorbent cue was generalized to an unconditioned, UVreflective cue. Ultraviolet vision contributes primarily to hue (not brightness) perception [1,7] and the cone-capture color space of a bird is four dimensional [i.e., tetrachromatic; 2]. Thus, four-dimensional paradigms are requisite for the investigation and understanding of generalization mechanisms for UV and human-visible cues among birds. Additional experiments are needed to investigate the functional and adaptive significance of UV vision among birds.

With regard to adaptive significance of UV vision for birds, foraging behavior may be considered as the ancestral function, and plumage signaling and mate choice may be regarded as evolutionarily secondary roles [5]. For sexual selection, experimental blocking of UV signals does not abolish mate preference among European starlings; rather, the presence and absence of UV signals change the criteria for mate choice [35]. Perhaps this premise can be applied to further investigations of avian feeding behavior. "Because humans lack UV vision, it is tempting to assume that this ability has some specific adaptive significance. It may, but the UV/violet-sensitive cone may just be a part of a general-purpose color vision system, and the relevant question instead is: why do humans lack UV vision?" [2].

Several chemical repellents and cues exhibit UV spectra, and might therefore be used in an application strategy including an initial application of a repellent and subsequent applications of a visual cue with spectral characteristics sufficiently similar to the repellent [36]. Similarly, bird management (e.g., UV-conditioned feeding behavior) is needed to protect human food and livestock feed from pathogens and zoonotic diseases currently associated with some wild birds [37-40]. Although it is probably no more meaningful to speak of "UV vision" in birds than to single out "blue vision" in humans [1], further experiments will be necessary to develop our understanding of UV vision associated with the sensory and behavioral ecology of wild birds within agronomic and natural environments.

\section{Acknowledgements}

Arkion Life Sciences (New Castle, DE, U.S.A.) provided the Avipel ${ }^{\circledR}$ repellent and Evonik Goldschmidt Corporation (Hopewell, VA, U.S.A.) provided the titanium dioxide for our experiments. Corporate collaborations do not imply endorsement by the United States Department of Agriculture. We sincerely appreciate the technical assistance provided by of G. Huibregtse (Colorado State University, Fort Collins, CO, U.S.A.) and S. Elen (BeyondVisible.com) for UV photography. We also thank T. C. Atwood, M. L. Avery, B. F. Blackwell, L. Clark, B. A. Kimball, F. D. Provenza, and M. E. Tobin for their thoughtful review of our manuscript.

\section{References}

[1] Cuthill IC, Partridge JC, Bennett ATD, Church SC, Hart NS, Hunt S. Ultraviolet vision in birds. Adv Stud Behav 2000;29:159-214. 
[2] Cuthill IC. Color perception. In: Hill GE, McGraw KJ, editors. Bird coloration. Mechanisms and measurementCambridge: Harvard University Press; 2006. p. 3-40.

[3] Huth HH, Burkhardt D. The spectral range of vision in Violetta hummingbirds Naturwissenschaften 1972;59:650.

[4] Wright AA. The influence of ultraviolet radiation on the pigeons' color discrimination. J Exp Anal Behav 1972;17:325-37.

[5] Bennett ATD, Cuthill IC. Ultraviolet vision in birds: what is its function? Vision Res 1994;34:1471-8.

[6] Maier EJ. To deal with the invisible: on the biological significance of UV sensitivity in birds. Naturwissenschaften 1993;80:476-8.

[7] Bennett ATD, Cuthill IC, Partridge JC, Maier EJ. Ultraviolet vision and mate choice in zebra finches. Nature 1996;380:433-5.

[8] Hunt S, Cuthill IC, Bennett ATD, Church SC, Partridge JC. Is the ultraviolet waveband a special communication channel in avian mate choice? J Exp Biol 2001;204:2499-507.

[9] Viitala J, Korpimaki E, Palokangas P, Koivula M. Attraction of kestrels to vole scent marks visible in ultraviolet light. Nature 1995;373:425-7.

[10] Church SC, Bennett ATD, Cuthill IC, Partridge JC. Ultraviolet cues affect the foraging behaviour of blue tits. Proc R Soc Lond B 1998;265:1509-14.

[11] Altshuler DL. Ultraviolet reflectance in fruits, ambient light composition and fruit removal in a tropical forest. Evol Ecol Res 2001;3:767-78.

[12] Honkavaara J, Koivula M, Korpimäki E, Siitari H, Viitala J. Ultraviolet vision and foraging in terrestrial vertebrates. Oikos 2002;98:505-11.

[13] Rajchard J. Ultraviolet (UV) light perception by birds: a review. Vet Med 2009;54: 351-9.

[14] Schaefer HM, McGraw K, Catoni C. Birds use fruit colour as honest signal of dietary antioxidant rewards. Funct Ecol 2008;22:303-10.

[15] Siitar H, Honkavaara J, Viitala J. Ultraviolet reflection of berries attracts foraging birds. A laboratory study with redwings (Turdus iliacus) and bilberries (Vaccinium myrtillus). Proc R Soc Lond 1999;266:2125-9.

[16] Honkavaara J, Siitari H, Viitala J. Fruit colour preferences of redwings (Turdus iliacus): experiments with hand-raised juveniles and wild-caught adults. Ethology 2004:110:445-57.

[17] Garcia J, Koelling RA. Relation of cue to consequence in avoidance learning. Psychon Sci 1966;4:123-4.

[18] Skinner BF. Selection by consequences. Science 1981;213:501-4.

[19] Avery ML. Avian repellents. In: Plimmer JR, editor. Encyclopedia of agrochemicals Hoboken: John Wiley \& Sons; 2002. p. 122-8.

[20] Mason JR, Reidinger Jr RF. Importance of color for methiocarb-induced food aversions in red-winged blackbirds. J Wildl Manage 1983;47:383-93.

[21] Werner SJ, Kimball BA, Provenza FD. Food color, flavor, and conditioned avoidance among red-winged blackbirds. Physiol Behav 2008;93:110-7.

[22] Chen D, Collins JS, Goldsmith TH. The UV receptor of bird retinas. Science 1984;225:337-9.
[23] Chen D, Goldsmith TH. Four spectral classes of cone in the retinas of birds. J Comp Physiol A 1986;159:473-9.

[24] Werner SJ, Provenza FD. Reconciling sensory cues and varied consequences of avian repellents. Physiol Behav 2011;102:158-63.

[25] Mason JR, Reidinger Jr RF. Generalization of and effects of pre-exposure on coloravoidance learning by red-winged blackbirds (Agelaius phoeniceus). Auk 1983;100:461-8.

[26] Zar JH. Biostatistical analysis. 4th edn. Upper Saddle River, NJ: Prentice-Hall, Inc.; 1999. p. $185-7$.

[27] Fraser CM, editor. The Merck veterinary manual. 7th edn. Rahway, NJ: Merck \& Company, Inc.; 1991. p. 1383

[28] Werner SJ, Carlson JC, Tupper SK, Santer MM, Linz GM. Threshold concentrations of an anthraquinone-based repellent for Canada geese, red-winged blackbirds, and ring-necked pheasants. Appl Anim Behav Sci 2009;121:190-6.

[29] Werner SJ, Linz GM, Tupper SK, Carlson JC. Laboratory efficacy of chemical repellents for reducing blackbird damage in rice and sunflower crops. J Wildl Manage 2010;74:1400-4.

[30] Werner SJ, Linz GM, Carlson JC, Pettit SE, Tupper SK, Santer MM. Anthraquinonebased bird repellent for sunflower crops. Appl Anim Behav Sci 2011;129:162-9.

[31] Leštan D, Podgornik H, Perdih A. Analysis of fungal pellets by UV-visible spectrum diffuse reflectance spectroscopy. Appl Environ Microbiol 1993;59:4253-60.

[32] Lyytinen A, Alatalo RV, Lindstrom L, Mappes J. Can ultraviolet cues function as aposematic signals? Behav Ecol 2001;12:65-70.

[33] Provenza FD. Postingestive feedback as an elementary determinant of food preference and intake in ruminants. J Range Manage 1995;48:2-17.

[34] Provenza FD, Villalba JJ. Foraging in domestic vertebrates: linking the internal and external milieu. In: Bels VL, editor. Feeding in domestic vertebrates: from structure to function. Oxfordshire: CABI; 2006. p. 210-40.

[35] Bennett ATD, Cuthill IC, Partridge JC, Lunau K. Ultraviolet plumage colors predict mate preferences in starlings. Proc Natl Acad Sci 1997;94:8618-21.

[36] Werner, SJ. Ultraviolet Strategy for Avian Repellency, U.S.A. Patent Application \#12/652,944; 2009.

[37] Daniels MJ, Hutchings MR, Greig A. The risk of disease transmission to livestock posed by contamination of farm stored feed by wildlife excreta. Epidemiol Infect 2003;130:561-8.

[38] Nielsen EM, Skov MN, Madsen JJ, Lodal J, Jespersen JB, Baggesen DL. Verocytotoxin-producing Escherichia coli in wild birds and rodents in close proximity to farms. Appl Environ Microbiol 2004;70:6944-7.

[39] Heaton JC, Jones K. Microbial contamination of fruit and vegetables and the behaviour of enteropathogens in the phyllosphere: a review. J Appl Microbiol 2008;104:613-26.

[40] Carlson JC, Franklin AB, Hyatt DR, Pettit SE, Linz GM. The role of starlings in the spread of Salmonella within concentrated animal feeding operations. J Appl Ecol 2011;48:479-86. 